GIORDANO LB; BOITEUX LS; QUEZADO-DUVAL AM; FONSECA MEN; RESENDE FV; REIS A; GONZÁLEZ M; NASCIMENTO WM; MENDONÇA JL. 2010. 'BRS Tospodoro': a high lycopene processing tomato cultivar adapted to organic cropping systems and with multiple resistance to pathogens. Horticultura Brasileira 28: 241-245.

\title{
'BRS Tospodoro': a high lycopene processing tomato cultivar adapted to organic cropping systems and with multiple resistance to pathogens
}

\author{
Leonardo de B Giordano; Leonardo S Boiteux; Alice M Quezado-Duval; Maria Esther de N Fonseca; \\ Francisco V Resende; Ailton Reis; Matías González; Warley Marcos Nascimento; José L Mendonça \\ ${ }^{1}$ National Center for Vegetable Crops Research (CNPH), Embrapa Vegetable Crops; C. Postal 218, 70359-970 Brasília-DF; ${ }^{2}$ Instituto \\ Nacional de Investigación Agropecuaria (INIA), Las Brujas, C. Postal 90200, Canelones, Uruguay; boiteux@enph.embrapa.br
}

\begin{abstract}
'BRS Tospodoro' is a high lycopene tomato cultivar, which combines multiple disease resistance genes and desirable processing traits. This cultivar was found to be suitable for both conventional and organic crop systems. 'BRS Tospodoro' was obtained via backcross breeding using 'Viradoro' as recurrent parent and the inbred line 'CNPH 1306' as the donor of the Pto gene (resistance to Pseudomonas syringae pv. tomato race 0). 'BRS Tospodoro' has the Mil-2 gene that controls resistance to root-knot nematodes (Meloidogyne incognita, M. javanica, and M. arenaria) as well as tolerance to populations of the aphid Macrosiphum euphorbiae (vector of Potyvirus species), and to whiteflies (Bemisia tabaci). 'BRS Tospodoro' has also the $S w-5 b$ gene, which controls resistance to major Tospovirus species (Groundnut ringspot virus, Tomato chlorotic spot virus, Chrysanthemum stem necrosis virus, and Tomato spotted wilt virus). This cultivar is also resistant to Stemphylium solani and S. lycopersici (Sm gene), Fusarium oxysporum f. sp. lycopersici race 1 (I-1 gene) and Verticillium dahlie race 1 (Ve gene). 'BRS Tospodoro' presents uniform fruit ripening, with the first harvest being done around 110 to 120 days after plant emergence. The fruits are firm, square-shaped, with an average weight of $46 \mathrm{~g}$ (in organic cropping) to above $70 \mathrm{~g}$ (in conventional cropping). The soluble solids content is in the range between 4.6 and $4.8^{\circ} \mathrm{Brix}$. The external fruit color is uniform (gene $u$ ) and bright red $\left(\mathrm{L}^{*}=44.1 ; \mathrm{a}^{*}=33.9 ; \mathrm{b}^{*}=20.4\right)$. The average lycopene content of mature fruits is $104 \mu \mathrm{g} / \mathrm{g}$. This cultivar has the jointless locus $(j 2)$, which facilitates both manual and mechanical harvesting. 'BRS Tospodoro' has determinate growth habit (locus $s p$ ) with vigorous foliage, which provides good fruit protection from sunscald. 'BRS Tospodoro' can be cultivated in all the traditional processing tomato-producing areas of Brazil without the need of any technical adjustment. 'BRS Tospodoro' displayed very good adaptation to the South Brazilian Region and South Cone of South America (Argentina and Uruguay), where P. syringae pv. tomato and Tospovirus are serious economic problems for the crop. 'BRS Tospodoro' might also be cultivated in traditional processing tomato-producing areas (SouthEast, North-East and Central Brazil), if geminivirus control measures are adopted. Due to its vigorous foliage, 'BRS Tospodoro' requires careful monitoring of the environmental conditions that favors late blight (Phytophthora infestans) epidemics. 'BRS Tospodoro' has been evaluated under organic crop systems with excellent performance in field assays conducted in Brasilia-DF, Brazil.
\end{abstract}

Keywords: Solanum lycopersicum, tomato, breeding, organic cropping.

\section{RESUMO}

'BRS Tospodoro': Cultivar de tomate para processamento com alto licopeno, adaptada aos sistemas de cultivo orgânico e com múltiplos genes de resistência a patógenos

'BRS Tospodoro' é uma cultivar de tomate para processamento industrial, rica no elemento antioxidante licopeno e adaptada a cultivos tanto convencionais quanto orgânicos. Esta cultivar é uma seleção derivada de um programa de retrocruzamentos entre a cultivar 'Viradoro' (usada como parental recorrente) e a linhagem 'CNPH 1306' (fonte doadora do gene Pto que controla resistência à Pseudomonas syringae pv. tomato raça 0). 'BRS Tospodoro' apresenta ainda o gene Mil-2 que condiciona resistência a Meloidogyne incognita, M. javanica e $M$. arenaria, bem como tolerância para populações do pulgão Macrosiphum euphorbiae (vetor de Potyvirus) e da mosca-branca (Bemisia tabaci). 'BRS Tospodoro' também possui o gene $S w-5 b$, que confere resistência a quatro espécies de Tospovirus (Groundnut ringspot virus, Tomato chlorotic spot virus, Chrysanthemum stem necrosis virus e Tomato spotted wilt virus). Esta cultivar também é resistente aos fungos Stemphylium solani e S. lycopersici (gene Sm), Fusarium oxysporum f. sp. lycopersici raça 1 (gene I-1) e Verticillium dahlie raça 1 (gene Ve). Possui hábito de crescimento determinado (gene $s p$ ) com excelente cobertura dos frutos. A colheita dos frutos maduros é feita em torno dos 110-120 dias após o transplantio (mudas com 25 dias de idade). Os frutos são firmes, de formato quadradooblongo, maturação uniforme (gene $u$ ), com coloração externa vermelha escura, brilhante $\left(L^{*}=44,1 ; a^{*}=33,9 ; b^{*}=20,4\right)$. O teor médio de licopeno em frutos totalmente maduros é de $104 \mu \mathrm{g} / \mathrm{g}$. O teor de sólidos totais variou entre 4,6 e $4,8{ }^{\circ}$ Brix e o peso médio dos frutos varia de $46 \mathrm{~g}$ (em cultivo orgânico) acima de $70 \mathrm{~g}$ (em cultivos convencionais). 'BRS Tospodoro' apresenta o pedúnculo destituído de camada de abscisão (gene $j 2$ ) e boa concentração de maturação de frutos. A cultivar mostrou excelente desempenho na Região Sul do Brasil e em cultivos no Cone Sul (Argentina e Uruguai), onde a infecção por Tospovirus e P. syringae pv. tomato são sérios problemas para a cultura. 'BRS Tospodoro' também é indicada para plantio nas principais regiões produtoras de tomate no Brasil (Sudeste, Nordeste e Centro-Oeste), desde que medidas preventivas de controle de geminiviroses sejam adotadas. Devido ao crescimento vigoroso de folhagem, 'BRS Tospodoro' requer monitoramento freqüente quando cultivado em condições ambientais que favoreçam a ocorrência de requeima (Phytophthora infestans). Esta nova cultivar mostrou excelente adaptação às condições de cultivo orgânico em ensaios conduzidos em Brasília-DF.

Palavras-chave: Solanum lycopersicum, tomate, melhoramento genético, cultivo orgânico. 
(Recebido para publicação em 1 de outubro de 2009; aceito em 18 de janeiro de 2010) (Received on October 1, 2009; accepted on January 18, 2010)

\section{THE ORIGIN}

'BRS Tospodoro' is a processing tomato (Solanum lycopersicum L.) cultivar, rich in the antioxidant lycopene and adapted to both conventional and organic crop systems. This cultivar displays multiple resistance genes to diseases and pests. 'BRS Tospodoro' was selected after self-pollinating plants of the fourth backcross generation during five cycles $\left(\mathrm{BC}_{4} \mathrm{~F}_{5}\right)$. The cultivar 'Viradoro' (Giordano et al., 2000) was used as the recurrent parent and the inbred line 'CNPH 1306' was employed as the donor of the Pto gene (which confers resistance to Pseudomonas syringae pv. tomato race 0 ). Resistant plants were identified after inoculation via immersion of the leaves into a suspension (adjusted to $10^{8} \mathrm{cfu} / \mathrm{mL}$ ) of $P$. syringae pv. tomato isolate ' $\mathrm{CNPH}$ 31 ' (collected in Venda Nova dos Imigrantes, Espírito Santo State, Brazil). Ten plants free of symptoms were selected in each backcross generation. Throughout all the selection stages, the cultivar 'Viradoro' (susceptible) and the inbred line 'CNPH 1306' (resistant) were used as controls. The final evaluation was carried out with the $P$. syringae pv. tomato isolate ' $\mathrm{CNPH} 31$ ' and also with the isolate 'CNPH 32' (collected in Patos de Minas, Minas Gerais State, Brazil), both classified as race 0 . Comparative assays and progeny tests indicated that the Pto gene was incorporated in the homozygous condition in 'BRS Tospodoro' (Figure 1).

\section{DESCRIPTION}

'BRS Tospodoro' presents a determinate growth habit (gene $s p$ ) and a dense canopy, which offer protection for the fruits against sunscald damage. The ripe fruits are harvested around 110-120 days after the transplanting (using 25-day old plantlets). Therefore, 'BRS Tospodoro' displays vegetative and reproductive cycles similar to that of the cultivar 'Viradoro' (Giordano et al., 2000). The average fruit weight ranged from $46 \mathrm{~g}$ (in organic cropping) to $70-85 \mathrm{~g}$ (in conventional cropping).
'BRS Tospodoro' does not contain abscission joint in the fruit pedicel (gene "jointless", $j 2$ ), which increases the manual harvesting efficiency to around $25 \%$ and also facilitates mechanical harvesting (Boiteux et al., 1995).

Nutritional characteristics and aspects of the fruits - The fruits of 'BRS Tospodoro' are firm, with uniform ripening (gene $u$ ) and oblongsquared shape (Figure 2). The soluble solid content ( $\left.{ }^{\circ} \mathrm{Brix}\right)$ in ripe fruits was estimated under open field conditions by using a digital refractometer (ATAGO model). In these assays, the Brix values varied from 4.6 to $4.8{ }^{\circ} \mathrm{Brix}$. The values of colorimetric readings for the skin color at the stage of complete ripening were obtained by a colorimeter "Tristimulus" (Minolta Model CR$200 \mathrm{~b}$ ), with $8 \mathrm{~mm}$ of the measured diameter area of the equipment with diffuse illumination (illuminant D65, vision angle of $0^{\circ}$ and chromatic space CIELAB). White ceramic tiles were employed to calibrate the system. The calibration values were: $\mathrm{L}^{*}=84.2$; $\mathrm{a}^{*}$
$=10.1$; and $\mathrm{b}^{*}=14.6$. 'BRS Tospodoro' displayed an external dark bright red color $\left(L^{*}=44.1 ; a^{*}=33.9 ; b^{*}=20.4\right)$. The ascorbic acid (vitamin C) content was determined by using the standard Tilmans titration method, which is based on the reduction of 2,6-sodiumdiclorophenolindophenol (DCFL) by the ascorbic acid (Pregnolatto \& Pregnolatto, 1985). An aliquot of $10 \mathrm{~mL}$ of the standard ascorbic acid solution was added to an Erlenmeyer bottle containing $50 \mathrm{~mL}$ of an oxalic acid solution. The DCFL solution was titrated until obtaining a solution of persistent pink color for 15 seconds (standardization). The amount (in $\mathrm{mg}$ ) of ascorbic acid in $100 \mathrm{~mL}$ of the samples was obtained through the following formula: $100 \mathrm{x} \mathrm{n}$ ' [ [n/5 x P]. In which: $\mathrm{n}$ ' = volume of DCFL (in $\mathrm{mL}$ ) consumed in the titrating samples; $\mathrm{V}=$ sample volume used in the titrating method; $\mathrm{n}$ $=$ volume of DCFL (in $\mathrm{mL}$ ) consumed in the standardization procedure and $\mathrm{P}$ $=$ weight of the sample $(\mathrm{g})$. The average ascorbic acid content in fruits of the

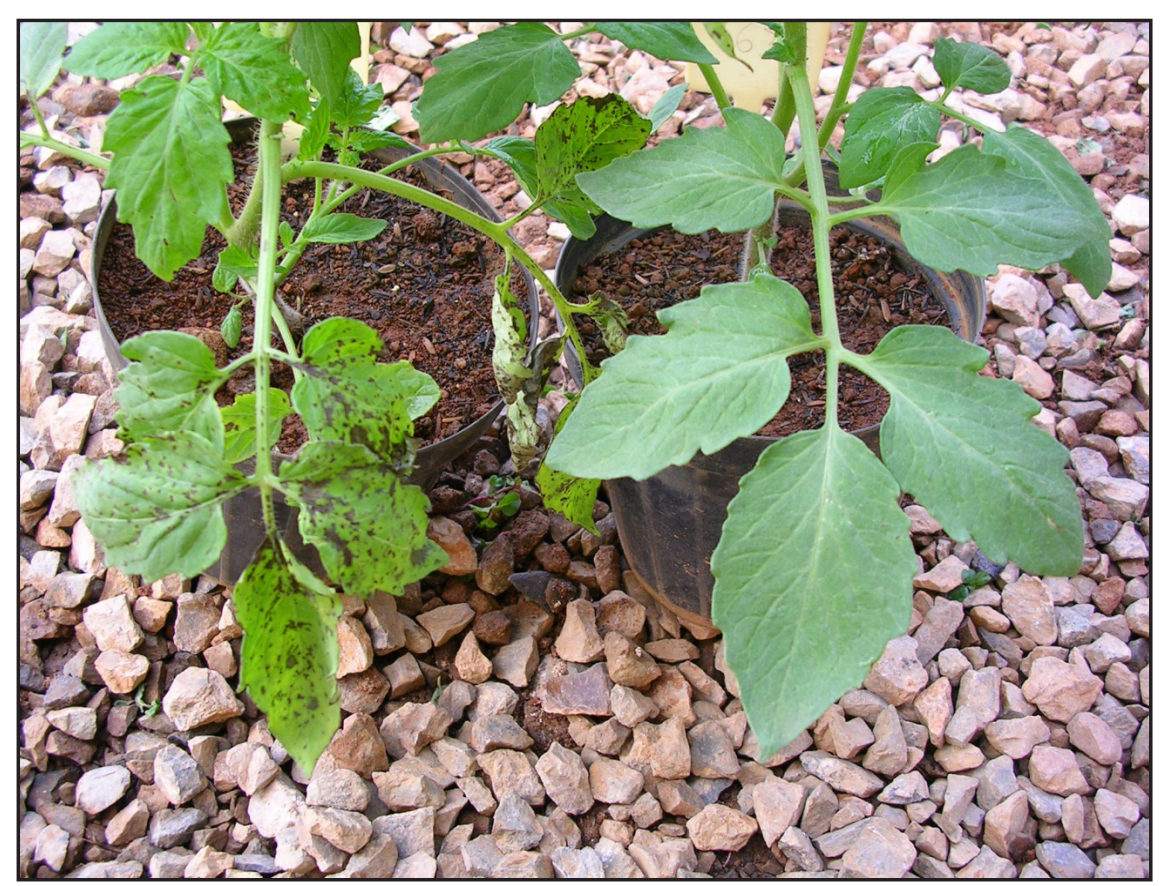

Figure 1. Resistant response to Pseudomonas syringae pv. tomato (race 0) controlled by the presence of the Pto gene in the cultivar 'BRS Tospodoro' (right) and the susceptible control 'Viradoro' (left) [Resposta de resistência a Pseudomonas syringae pv. tomato, raça 0, conferidos pelo gene Pto presente na cultivar 'BRS Tospodoro' (direita) e ausente na cultivar suscetível ‘Viradoro’ (esquerda)]. Brasília, Embrapa Hortaliças, 2008. 


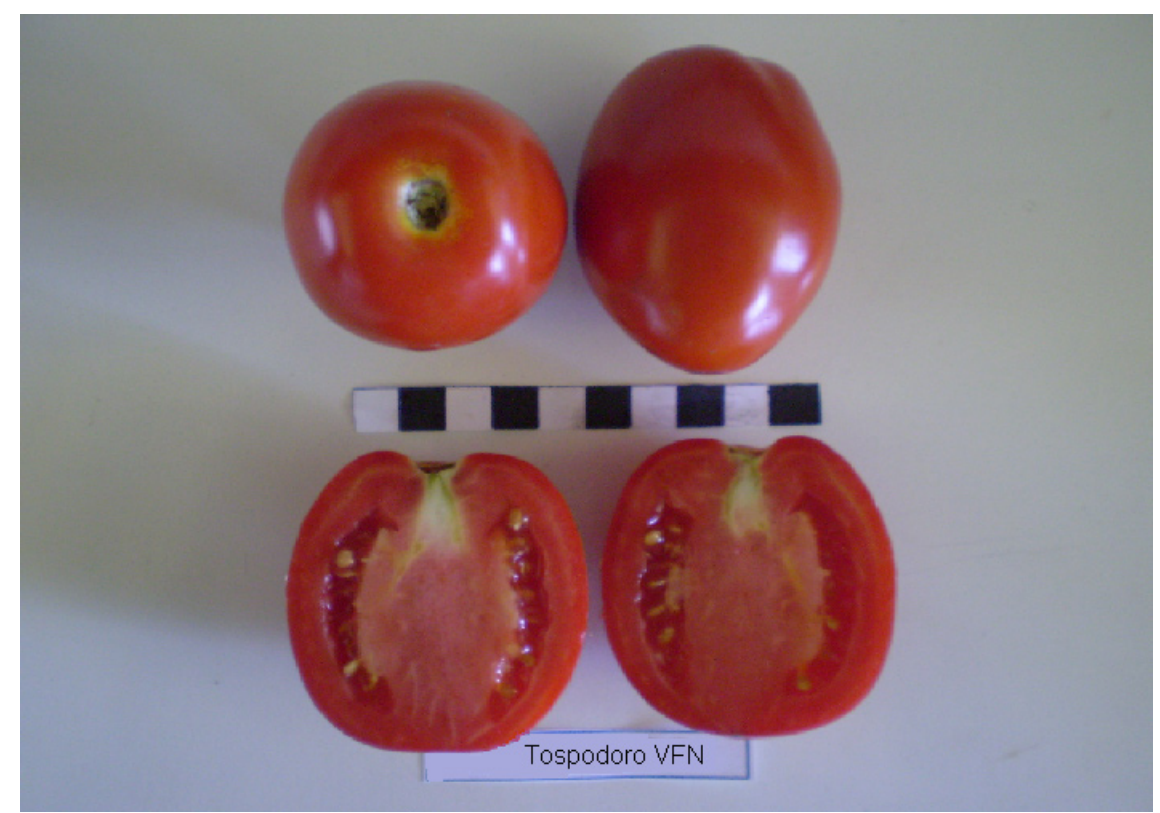

Figure 2. Fruit characteristics of the cultivar 'BRS Tospodoro' (características dos frutos da cultivar 'BRS Tospodoro'). Brasília, Embrapa Hortaliças, 2008.

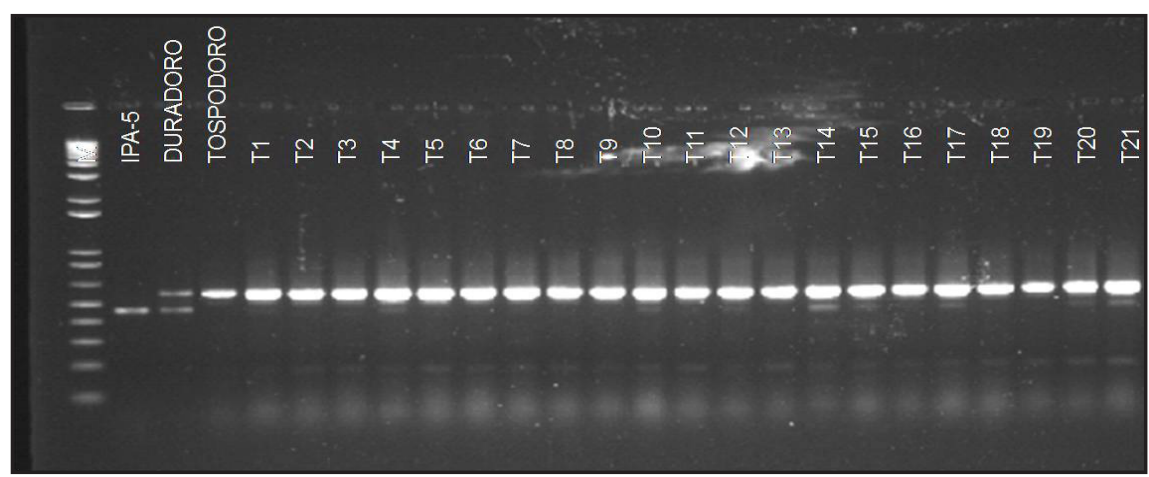

Figure 3. Marker-assisted selection using the Sw-5-2 primer pair (Dianese et al., 2010). 'IPA-5' (homozygous susceptible cultivar), 'Duradoro' (heterozygous resistant hybrid), and 'BRS Tospodoro' (homozygous resistant for the $S w-5$ locus). Samples from T1 to T21 are the eletrophoretic profiles obtained from DNA extracted of individual 'BRS Tospodoro' plants randomly chosen for this marker-assisted analysis [seleção assistida com o par de 'primers' Sw-5-2 (Dianese et al., 2010). 'IPA-5' (cultivar homozigota suscetível), 'Duradoro' (híbrido heterozigoto resistente) e 'BRS Tospodoro' (homozigoto para o lócus Sw-5). Amostras T1 até T21 representam o perfil eletroforético do DNA extraído de plantas de 'BRS Tospodoro' colhidas ao acaso para análise via marcadores]. Brasília, Embrapa Hortaliças, 2008.

cultivar 'BRS Tospodoro' was $27 \mathrm{mg}$ in $100 \mathrm{~mL}$ of juice (filtered). Currently, the daily recommended intake of vitamin C is $60 \mathrm{mg} /$ day (Carr \& Frei, 1999).

Analysis of amount of lycopene and determination of carotenoids types in mature fruits - Evaluation was done through the extraction of total carotenoids with ketone and followed by "High Performance Liquid Chromatography" (HPLC) analysis in C18 polymeric column. A mixture of acetonitrile: methanol: ethyl acetate was employed as a movable phase mature fruits. This lycopene amount of 'BRS Tospodoro' was also confirmed via colorimetric analysis (Carvalho et al., 2005). Lycopene confers the typical red color of the tomato fruit and presents high antioxidant activity.This molecule has an outstanding nutraceutical action, which helps to prevent cardiovascular problems as well as prostate and ovarian cancer (Rao \& Agawal, 2000; Smidt \& Burke, 2004).

Fruit viscosity - Samples containing $1.3 \mathrm{~kg}$ of fruits were put into a microwave oven (frequency of 2450 megacycles and input power of $950 \mathrm{~W}$ ) for 12 minutes in order to inactivate the enzymes. After staying in the microwave oven, the samples were weighed again and then, with the use of distilled water, their original weight was reestablished. The samples were grinded in a multiprocessor (National MJC 13) and the pulp passed by a strainer with holes of $0.8 \mathrm{~mm}$ of diameter. After that, the air was taken out from the samples by a vacuum pump for about 2 minutes. The viscosity was measured using a Bostwick viscosimeter (consistometer). The viscosity results were reported as the distance traveled $(\mathrm{cm})$ in $30 \mathrm{sec}$ at $25^{\circ} \mathrm{C}$ (Barret et al., 1998). The viscosity means obtained for 'BRS Tospodoro' was $13 \mathrm{~cm}$ in 30', indicating that the fruits are adequate for the production of items like "Ketchup".

Resistance to diseases - Besides the gene Pto (qualitative resistance to $P$. syringae pv. tomato race 0 ), 'BRS Tospodoro' contains the locus $S w-5$ in homozygous condition. Such locus contains the gene $S w-5-b$, which controls a resistant reaction to distinct species of the Tospovirus complex found in South America (Boiteux \& Giordano, 1993; Dianese et al., 2010), including Groundnut ringspot virus, Tomato chlorotic spot virus, Chrysanthemum stem necrosis virus, and Tomato spotted wilt virus. The resistance evaluation to Tospovirus was carried out as described by Giordano et al. (2000) and confirmed via molecular markers specific for this genomic region (Dianese et al., 2010). The marker-assisted analysis confirmed that 'BRS Tospodoro' does not segregate for the locus $S w-5$ (Figure 3). The selection for resistance to the root-knot 
Table 1. Yield and number of fruits per plant, mean fruit weight of 'BRS Tospodoro' and commercial tomato cultivars, advanced lines and experimental hybrids in an organic production system (produção, número de frutos por planta, peso médio de fruto e produtividade da cultivar 'BRS Tospodoro' e de cultivares comerciais de tomate, linhagens avançadas e híbridos experimentais em sistema orgânico de produção). Brasília, Embrapa Hortaliças, 2008.

\begin{tabular}{lcccc}
\hline Cultivar & $\begin{array}{c}\text { Mean fruit weight } \\
(\mathbf{g})\end{array}$ & $\begin{array}{c}\text { Number } \\
\text { fruits } / \mathbf{p l a n t}\end{array}$ & $\begin{array}{c}\text { Yield/plant } \\
(\mathbf{k g})\end{array}$ & $\begin{array}{c}\text { Yield } \\
(\mathbf{t} / \mathbf{h a})\end{array}$ \\
\hline HEI - 013 & $54.42 \mathrm{a}^{*}$ & $56.15^{* *}$ & 3.01 & $70.99 \mathrm{a} *$ \\
BRS Tospodoro & $46.22 \mathrm{~b}$ & 64.85 & 3.00 & $70.59 \mathrm{a}$ \\
HEI - 014 & $51.20 \mathrm{~b}$ & 57.74 & 2.96 & $66.28 \mathrm{a}$ \\
HEI - 012 & $53.79 \mathrm{a}$ & 53.74 & 2.89 & $66.09 \mathrm{a}$ \\
HEI - 015 & $48.71 \mathrm{~b}$ & 56.92 & 2.76 & $61.80 \mathrm{a}$ \\
HEI - 016 & $47.34 \mathrm{~b}$ & 55.97 & 2.62 & $61.78 \mathrm{a}$ \\
LAI - 023 & $45.14 \mathrm{~b}$ & 58.98 & 2.65 & $58.03 \mathrm{a}$ \\
HEI - 018 & $49.87 \mathrm{~b}$ & 51.52 & 2.58 & $57.68 \mathrm{a}$ \\
LAI - 082 & $50.72 \mathrm{~b}$ & 50.58 & 2.56 & $54.19 \mathrm{~b}$ \\
LAI - 002 & $57.58 \mathrm{a}$ & 40.55 & 2.33 & $53.60 \mathrm{~b}$ \\
Viradoro & $48.41 \mathrm{~b}$ & 48.03 & 2.33 & $53.54 \mathrm{~b}$ \\
Nemadoro & $61.99 \mathrm{a}$ & 35.37 & 2.19 & $51.63 \mathrm{~b}$ \\
HEI - 017 & $50.38 \mathrm{~b}$ & 40.70 & 2.03 & $47.83 \mathrm{~b}$ \\
Caline IPA-6 & $57.04 \mathrm{a}$ & 34.47 & 1.97 & $46.51 \mathrm{~b}$ \\
\hline CV(\%) & 10.31 & 42.41 & 55.68 & 17.84 \\
\hline
\end{tabular}

${ }^{*}$ Means followed by the same letters (in the columns) are not significant different (ScottKnott test, 5\%) (médias seguidas pela mesma letra na coluna não diferem entre si pelo teste de Scott-Knott, 5\%).

nematodes was carried out essentially as described by Charchar et al. (2003) and via molecular markers. The presence of gene Mil-2 demonstrates simultaneous resistance to "root-knot nematodes" (Meloidogyne incognita, $M$. javanica, and $M$. arenaria); tolerance to populations of the aphid Macrosiphum euphorbiae (vector of Potyvirus) (Rossi et al., 1998) as well as tolerance to Bemisia tabaci biotypes (Nombela et al., 2003). 'BRS Tospodoro' displayed resistant reaction to Fusarium oxysporum f. sp. lycopersici race 1 (gene I-1), Stemphylium solani and S. lycopersici (gene $\mathrm{Sm}$ ) and Verticillium dahlie race 1 (gene Ve). The selection of resistant plants to these three fungal diseases was carried out as described by Santos (1997).

Technical recommendations for cultivation in Brazil - 'BRS Tospodoro' demonstrated adaptation to the Southern Region of Brazil, where the infection by Tospovirus and $P$. syringae pv. tomato are serious problems for the crop. 'BRS Tospodoro' might also be indicated for planting in the major processing tomato- number of dominant resistance genes) makes the 'BRS Tospodoro' a promising parental inbred line for use in breeding programs aiming to develop $F_{1}$ tomato hybrids.

\section{The evaluation of 'BRS Tospodoro'} in Uruguay - This cultivar also demonstrated high productivity and resistance to Tospovirus isolates in experimental fields conducted in Argentina and Uruguay. This cultivar was evaluated under conventional crop conditions in Uruguay, in 2006-2007 (González et al., 2007). The prevalent environmental conditions were of pluviometric precipitations at the end of the cycle. Under such conditions, 'BRS Tospodoro' presented a productivity of $57 \mathrm{t} /$ ha (Table 2), soluble solid content between 4.3 and $4.7^{\circ} \mathrm{B}$ and average fruit weight of $80 \mathrm{~g}$. In these field assays, the performance of 'BRS Tospodoro' did not demonstrate significant differences in productivity in relation to the cultivars commercially-used in Uruguay. The high levels of field resistance of 'BRS Tospodoro' to Tospovirus were also confirmed in this assay. The susceptible hybrid 'Red Summer' presented $11.1 \%$ of infected plants, whereas 'BRS Tospodoro' demonstrated all plants free of symptoms. In the second year of evaluation, with a more favorable environmental condition, 'BRS Tospodoro' yields were $92.4 \mathrm{t} / \mathrm{ha}$, average fruit weight of $85.3 \mathrm{~g}$ and soluble solid content around 4.13 ${ }^{\circ} \mathrm{B}$ (González et al., 2008). 'BRS Tospodoro' was also evaluated by small farmers in the South of Uruguay, demonstrating excellent adaptation. The foliage sanity, the size and firmness of the fruits as well as the "jointless" trait were the most relevant characteristics considered by the farmers of the familybased crop systems in Uruguay.

\section{AVAILABILITY OF SEEDS}

Embrapa Vegetable Crops will keep the genetic seeds in stock and has carried out multiplication of the basic seeds.

\section{ACKNOWLEDGEMENTS}

The authors thank Antonio Francisco 
Table 2. Yield and mean fruit weight of 'BRS Tospodoro' compared with commercial cultivars employed under conventional cropping system (2006-2007). Planting density of 29,300 plants/ha [produtividade e peso médio de frutos da cultivar 'BRS Tospodoro' e um conjunto de cultivares comerciais utilizadas no Uruguai em condições de plantio convencionais. Densidade de plantio de 29.300 plantas/ha. INIA), Las Brujas, Canelones, Uruguai].

\begin{tabular}{lcc}
\hline Cultivar & Yield (t/ha) & Mean fruit weight (g) \\
\hline Cuyano & $61.3 \mathrm{a}^{*}$ & $87.5 * *$ \\
HMX 3860 & $61.2 \mathrm{a}$ & 78.4 \\
H 6803 & $60.0 \mathrm{a}$ & 64.8 \\
Loica & $58.6 \mathrm{a}$ & 75.2 \\
BRS Tospodoro & $57.2 \mathrm{a}$ & 80.8 \\
H 9997 & $57.0 \mathrm{a}$ & 86.1 \\
HMX 3861 & $55.1 \mathrm{a}$ & 71.2 \\
IPA 6 & $54.9 \mathrm{a}$ & 56.8 \\
Rio Grande & $54.3 \mathrm{a}$ & 108.8 \\
York & $54.0 \mathrm{a}$ & 71.0 \\
Fortune & $50.0 \mathrm{a}$ & 70.9 \\
Donald & $49.5 \mathrm{a}$ & 45.8 \\
Red Summer & $45.3 \mathrm{~b}$ & 84.6 \\
HMX 2853 & $41.1 \mathrm{~b}$ & 84.7 \\
H 9663 & $40.8 \mathrm{~b}$ & 102.0 \\
UG 86 & $38.9 \mathrm{~b}$ & 110.8 \\
H 5803 & $36.7 \mathrm{~b}$ & 116.8 \\
H 8204 & $29.2 \mathrm{~b}$ & 64.2 \\
\hline CV $(\%)$ & 17.15 & 19.1 \\
\hline
\end{tabular}

*Means followed by the same letters (in the column) are not significant different (Scott-Knott test, $5 \%$ ); **Samples of 30 fruits (médias seguidas pela mesma letra na coluna não diferem entre si pelo teste de Scott-Knott, 5\%; amostra de 30 frutos).

Costa, William Pereira Dutra, and Antonio Régis de Oliveira for their valuable technical support (Embrapa Vegetable Crops). The authors also thank Juliana Feitoza da Cunha and Elaine Dias da Silva (students of the Chemistry Graduation Course at UnB) for the qualified support in the analysis of carotenoids and determination of the vitamin $\mathrm{C}$ contents.

\section{REFERENCES}

BARRETT DM; GARCIA E; WAYNE JE. 1998. Textural modification of processing tomatoes. Critical Reviews in Food Science and Nutrition 38:173-258

BOITEUX LS; GIORDANO LB. 1993. Genetic basis of resistance against two Tospovirus species in tomato (Lycopersicon esculentum).
Euphytica 71: 151-154.

BOITEUX LS; GIORDANO LB; FURUMOTO O; ARAGÃO FAS. 1995. Estimating the pleiotropic effect of the jointless-2 gene on the processing and agronomic traits of tomato by using near-isogenic lines. Plant Breeding 114: 457-459.

CARR AC; FREI B. 1999. Toward a new recommended dietary allowance for vitamin $\mathrm{C}$ based on antioxidant and health effects in humans. American Journal Clinical Nutrition 69: 1086-1107.

CARVALHO W; FONSECA MEN; SILVA HR; BOITEUX LS; GIORDANO LB. 2005. Estimativa indireta de teores de licopeno em frutos de genótipos de tomateiro via análise colorimétrica. Horticultura Brasileira 23: 819-825.

CHARCHAR JM; GIORDANO LB; BOITEUX LS. 2003. Metodologia para seleção de hortaliças com resistência a nematóides: Famílias Convolvulaceae e Solanaceae / Meloidogyne spp. Embrapa Hortaliças,
Brasília-DF, Comunicado Técnico 21. 4p. DIANESE EC; FONSECA MEN; GOLDBACH R; KORMELINK R; INOUE-NAGATA AK; RESENDE RO; BOITEUX LS. 2010. Development of a locus-specific, co-dominant SCAR marker for assisted-selection of the Sw-5 (Tospovirus resistance) gene cluster in a wide range of tomato accessions. Molecular Breeding 25: 133-142.

GIORDANO LB; DE ÁVILAAC; CHARCHAR JM; BOITEUX LS; FERRAZ E. 2000. 'Viradoro': A Tospovirus-resistant processing tomato cultivar adapted to tropical environments. HortScience 35: 1368-1379.

GONZÁLEZ, M; BERRUETA, C. 2008. Evaluación de cultivares de tomate para industria (ciclo 2007/2008). En: Jornada técnica de divulgación en el cultivo de tomate. Serie Actividades de Difusión No 537. Canelones, Uruguay. p 4-14.

GONZALEZ M; BERRUETA C; CARBALLO S. 2007. Evaluación de cultivares de tomate para industria zafra 2006/07. Serie Actividades de Difusión $N^{\circ}$ 494. Canelones, Uruguay. INIA.

NASSUR RCMR; RESENDE FV; GIORDANO LB; BOITEUX LS. 2007. Avaliação de híbridos e cultivares de tomate de hábito determinado em sistema orgânico de produção. Horticultura Brasileira 25: S75-S76.

NOMBELA G; WILLIAMSON VM; MUNIZ M. 2003. The root-knot nematode resistance gene Mil-2 of tomato is responsible for resistance the whitefly Bemisia tabaci. Molecular PlantMicrobe Interactions 16: 645-649.

PREGNOLATTO W; PREGNOLATTO NP. 1985. Normas analíticas do Instituto Adolfo Lutz: Métodos químicos e físicos para análise de alimentos. $3^{\text {a }}$ ed. São Paulo: Instituto Adolfo Lutz, v.1, 533p.

RAO AV; AGAWAL S. 2000. Role of antioxidant lycopene in cancer and heart disease. Journal of the American College of Nutrition 19: 563-569.

RODRIGUEZ-AMAYA D. 2001. A Guide to Carotenoids Analysis in Food. Washington: International Life Sciences Institute Press, $64 \mathrm{p}$.

ROSSI M; GOGGIN FL; MILLIGAN SB; KALOSHIAN I; ULLMAN DE; WILLIAMSON VM. 1998. The nematode resistance gene $\mathrm{Mi}$ of tomato confers resistance against the potato aphid. Proceedings of the National Academy of Sciences USA 95: 9750-9754.

SANTOS JRM. 1997. Methodology for screening tomato for Fusarium wilt, Verticillium wilt, gray leaf spot, early blight and Septoria leaf spot. In: Proceedings of the First International Symposium on Tropical Tomato Diseases. ASHS Press, EUA, 164-166.

SMIDT CR; BURKE DS. 2004. Nutritional significance and measurement of carotenoids. Current Topics in Nutraceutical Research 2: 79-91. 